\title{
DNA Microarray Analysis of Pancreatic Malignancies
}

\author{
Regine Brandt ${ }^{a}$ Robert Grützmann ${ }^{b}$ Andrea Bauer ${ }^{c}$ Ralf Jesenofskya,d \\ Jörg Ringela Matthias Löhra,d Christian Pilarsky ${ }^{b}$ Jörg D. Hoheiselc \\ aDepartment of Medicine II, Mannheim Medical Faculty, University of Heidelberg; bDepartment of Visceral, \\ Thoracic and Vascular Surgery, University Hospital Carl Gustav Carus, Technical University of Dresden; \\ cDivision of Functional Genome Analysis, and dMolecular Gastroenterology Unit, \\ Deutsches Krebsforschungszentrum (DKFZ), Heidelberg, Germany
}

\section{Key Words}

Pancreatic ductal carcinoma - Microarray · Gene

expression profiling $\cdot$ Cancer, pancreas

\begin{abstract}
Pancreatic ductal adenocarcinoma (PDAC) has an extremely poor prognosis. To improve the prognosis, novel molecular markers and targets for earlier diagnosis and adjuvant and/or neoadjuvant treatment are needed. Recent advances in human genome research and highthroughput molecular technologies make it possible to cope with the molecular complexity of malignant tumors. With DNA array technology, mRNA expression levels of thousand of genes can be measured simultaneously in a single assay. As several studies using microarrays in PDAC have already been published, this review attempts to compare the published data and therefore to validate the results. In addition, the applied techniques are discussed in the context of pancreatic malignancies.
\end{abstract}

Copyright $@ 2004$ S. Karger AG, Basel and IAP

Regine Brandt and Robert Grützmann contributed equally to this study.

\begin{tabular}{ll}
\hline KARGER & (c) 2004 S. Karger AG, Basel and IAP \\
1424-3903/04/0046-0587\$21.00/0 \\
$\begin{array}{l}\text { Fax +41 61306 1234 } \\
\begin{array}{l}\text { E-Mail karger@karger.ch } \\
\text { www.karger.com }\end{array}\end{array}$ & $\begin{array}{l}\text { Accessible online at: } \\
\text { www.karger.com/pan }\end{array}$
\end{tabular}

\section{Introduction}

Pancreatic cancer is the fourth leading cause of cancer death in the United States [1] and the sixth leading cause of cancer deaths in Germany [2]. The World Health Organization estimates 112,000 cases worldwide for the year 2000. It is a common disease with a very poor prognosis. The frequent diagnosis at late stages of the disease limits the role of surgery as a curative modality. Despite advanced technologies in therapy and diagnostics, the 5-year survival rate remains less than $5 \%$ and generally the survival time after diagnosis is 3-6 months. About $95 \%$ of pancreatic cancers are ductal adenocarcinomas (PDACs), $5 \%$ are islet cell tumors. Development of pancreatic cancer is a multi-stage process resulting from the accumulation of genetic changes in somatic cells. Activating mutations of the k-ras oncogene are found in virtually all cases of pancreatic cancer and are early events in tumorigenesis [3-6]. Mutations in tumor suppressors, such as p16INK4a [7-9], p53 [8, 10-12] and DPC4/SMAD4 [13], appear to occur as a second step in advanced tumorigenesis. The identification of alterations in gene expression that occur during tumorigenesis may provide information for the early diagnosis of pancreatic cancer. Gene expression can be analyzed by various methods: differential dis-

\footnotetext{
Jörg D. Hoheisel, $\mathrm{PhD}$

Division of Functional Genome Analysis, Deutsches Krebsforschungszentrum Im Neuenheimer Feld 580

DE-69120 Heidelberg (Germany)

Tel. +496221 424680, Fax +496221 424682, E-Mail j.hoheisel@dkfz.de
} 
play RT-PCR; representational difference analysis; sequencing expressed sequence tags (ESTs) or short fragment tags produced during a process called sequential analysis of gene expression (SAGE), and finally DNAmicroarray technology. All these methods were developed for comparative studies allowing a systematic screening for molecular differences at the level of mRNA expression in different cells or tissues.

Differential display is based on an amplification of messenger RNA 3'-termini using an anchored oligo-dT primer at one end and a short primer with an arbitrary sequence at the other end. The amplified cDNAs, labelled with a radioisotope, are then separated on a denaturing polyacrylamide gel and visualized by autoradiography or phosphorimaging. Side-by-side comparison of mRNA species from two or more related samples allows an identification of both up- and downregulation of the genes of interest [14].

Representational differential analysis [15] and related procedures take advantage of the competition between identical sequences for complementary DNA. In combination with a selective PCR amplification step, this allows a subtractive and kinetic enrichment of genes that are differentially transcribed in two samples. Such studies identified many genes that are over- or underexpressed in pancreatic cancer tissue $[16,17]$. The procedure has the advantage of selecting with all transcripts; it lacks the ability of (easy) quantification, however.

The availability of large EST and SAGE-tag libraries make comparative EST or SAGE-tag counting possible. Libraries of identical sources can be pooled and the occurrence of sequences that are specific for a particular gene is determined by sequencing. Also, large databases of this kind exist (e.g., http://www.ncbi.nlm.nih.gov/) and can be used for in silico analyses. Tag counting has been successfully applied to pancreatic cancer [18]. Both methods, however, lack the potential for high-throughput analyses on a routine basis.

Recent developments in human genome research and technical advances in molecular biology procedures made DNA microarray technology the method of choice for gene expression analyses. This technology is capable to cope with the molecular complexity of malignant tumors, since the mRNA expression levels of thousands of genes can be measured simultaneously in a single assay. By such means, it is now possible to distinguish tumor subclasses by gene expression profiles and to identify new diagnostic and prognostic biomarkers as well as potential therapeutic targets.

\section{Background of Chip Technology}

The power of DNA microarrays as experimental tools derives from the specificity and relatively strong affinity of duplex formation of complementary sequences. In 1965, Gillespie and Spiegelman [19] observed that singlestranded DNA binds strongly to nitrocellulose membranes in a way that prevents the strands from re-associating with each other, but permits hybridization to complementary RNA. Development of a blotting technique by Southern [20] proved to be a milestone in assaying nucleic acids. Clone filter arrays were introduced by Lerach and colleagues [21] permitting a reverse analysis format in transcript analysis. Rather than studying global preparations of nucleic acids sequentially with individual probes, they presented the unique DNA content of very many recombinant library clones in an ordered manner, to which global RNA samples could be hybridized. The resulting parallelism in data production was a crucial step toward genome-wide analyses, as indicated by early results from pancreatic cancer samples done by Gress et al. [22]. In situ synthesis of oligonucleotide arrays [23, 24] and the arraying of prefabricated fragments of nucleic acids on glass surfaces [25] made such arrays more readily available.

Today, several options exist on how to create microarrays. Frequently, PCR products are arrayed in-house using spotting robots [26-28]. Also, a broad assortment of commercially available arrays exists [29]. Currently one of the most frequently used systems for global transcriptional profiling analysis is that from Affymetrix. Their arrays are produced by photolithographically controlled in situ oligonucleotide synthesis. Up to one million probes could be synthesized on an array of $1.28 \times 1.28 \mathrm{~cm}$ [30]. A big disadvantage of this system is the fact that the chip design cannot be modified easily. Especially for tailormade arrays assaying only the genes relevant to the respective disease, global arrays represent an expensive overkill. However, newly developed systems, such as the Geniom device developed by febit [31] for example, allow a flexible design of the probe composition. Based on electronically controlled micromirrors, the time-consuming and expensive production of photolithographic masks is avoided. Therefore, microarrays of any probe content can be produced on site, nevertheless using the high resolution of photo-controlled synthesis; only a file of oligonucleotide sequences is required. Also, the chip can be subdivided into up to eight separate entities, thereby adapting the number of probe molecules to the actual need of the respective analysis. 
Table 1. Published PDAC microarray analyses

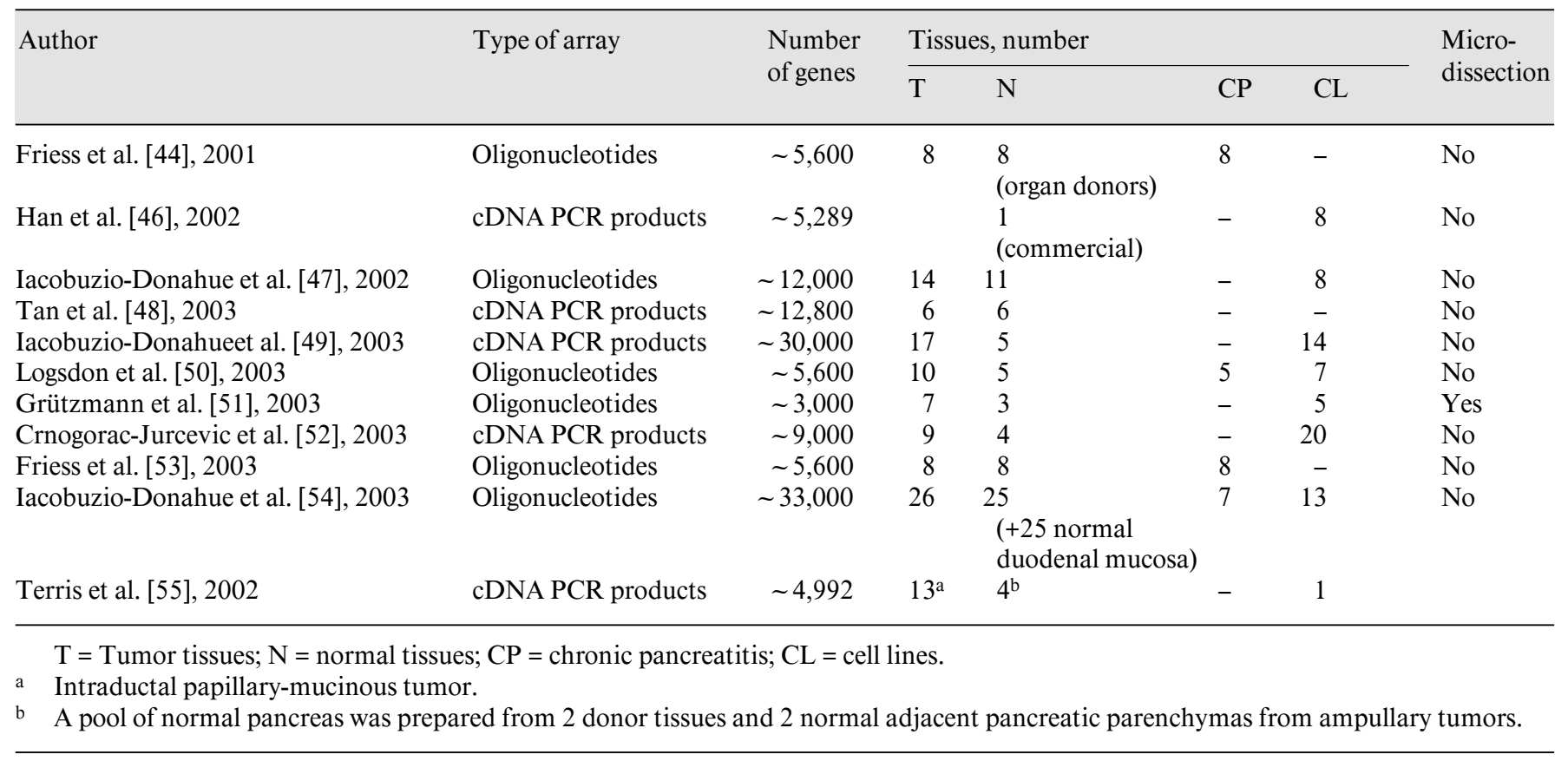

Beyond transcriptional profiling, there is a large variety of other analysis types that can be performed on microarrays. The detection of single nucleotide polymorphisms [32], comparative genomic hybridization [33] or studies on epigenetic variation [34] for example, could become as important for diagnosis and prognosis as the analysis on the transcript level.

\section{Advances in Research on Pancreatic Cancer Using Microarray Technology}

Gene expression profiling has been applied to a variety of tumors such as breast [35], colon [36-38], prostate [39], esophagus [40] and the stomach [41]. In pancreatic cancer, several analyses using methods other than microarrays were performed to elucidate gene expression changes [17, 18, 42-45]. In addition, 11 studies of pancreatic tumors by DNA microarray technology have been published to date [44, 46-55] (table 1). These studies identified large sets of new class-II cancer genes [56] revealing dysregulation at the level of transcription. However, as noticed earlier [57], the published results are not easily comparable, because of the different hybridization platforms and data analysis procedures that were applied. In addition, the samples were not picked from a defined cohort of patients. Nevertheless, this article aims at an ini- tial cross-validation of the published data on genes that are differentially expressed in normal and neoplastic pancreatic cells in order to define new markers or potentially interesting target entities, which are urgently required for an improved diagnosis and treatment.

\section{Microarray Technology: How to Find Differentially Expressed Genes}

Performing microarray experiments entails a twofold challenge. First and foremost is the correct performance of the experimental part. Already the preparation of the RNA is not easily performed and most critical to all subsequent steps especially in pancreatic tissues. Any difference in how the tissue is being isolated will immediately translate into changes in the transcript level. Given the fact that some mRNA molecules have a half life of a few seconds only, it is very likely that artificial variations will be seen for some mRNA molecules, regardless of the method applied. It is critical and possible, however, to freeze, literally, the transcript status of a tissue as quickly as technically possible in order to extract meaningful data.

Also the second part, the identification of significantly differentially transcribed genes from the total information generated on microarrays, is not trivial. To date, there is no gold standard for performing these bio-informatic 
Table 2. Useful databases and software tools

\begin{tabular}{lll}
\hline Name & URL & Description \\
\hline ArrayExpress & http://www.ebi.ac.uk/arrayexpress/ & Data collection and software source \\
GEO & http://www.ncbi.nlm.nih.gov/geo/ & Data collection and software source \\
SMD & $\mathrm{http://genome-www5.stanford.edu/}$ & Data collection and software source \\
M-CHiPS & $\mathrm{http} / / /$ www.mchips.org & Data collection and software source \\
SAM & $\mathrm{http://www-stat.stanford.edu/}$ tibs/SAM/ & Data analysis software \\
Base & $\mathrm{http://base.thep.lu.se//}$ & Open source database software \\
GenePattern & $\mathrm{http://www-genome.wi.mit.edu/cancer/software/software.html}$ & Data analysis software \\
BioConductor & $\mathrm{http://biosun1.harvard.edu/complab/dchip/}$ & Software source \\
\hline
\end{tabular}

analyses, but some general rules are emerging. Normalization, for example, is mostly performed globally based on an average intensity level on a microarray. Only rarely is it based on a selection of genes which are considered to be not differentially expressed $[58,59]$. The former process is mostly much more robust. Still, it may lead to false interpretation [60]. Also, the definition of a globally applicable threshold is impossible, since such a value depends on all experimental factors and therefore differs from experiment to experiment. Only statistical analyses, such as the 'significance analysis of microarrays' package [61], permit a sensible analysis. Minimal standards on how to perform transcriptional profiling analyses on microarrays were discussed and defined by the MGED consortium (www.mged.org) [62]. Next to commercial software, several program packages exist that are freely available to academic users (table 2).

\section{Gene Validation}

If performed according to strict statistical procedures, the measurement of differential gene expression with microarrays can be a very reliable method. In a global setting, cross-validation of the results with other array experiments enables an evaluation of data quality, simply by increasing the number of experiments that are taken into account. The feasibility of this approach was demonstrated by Rhodes et al. [63] and is actually the aim of this review with respect to pancreatic cancer. For individual transcripts, quantitative PCR [64] is an even more precise instrument for the measurement of differential RNA levels but lacks power with respect to throughput. Last, it is well known that variations in RNA level do not necessarily correlate with variations in protein level. Therefore, analysis of the actual protein expression may eventually supersede transcript profiling, at least for target identification.

\section{Transcript Variations in Pancreatic Tumors}

The results from several groups show that gene expression profiling of pancreatic tumors using high-density arrays yields meaningful data, if performed appropriately. In total, 978 genes were found to be differentially transcribed in pancreatic tumors. Table 3 combines the results of the currently available publications listed in table 1. Only genes that were found in at least 2 studies are listed, producing a catalogue of 148 genes. There are several potential reasons for this low concordance between the studies. First, the type, histology and number of samples used (i.e., established cell lines or human pancreatic cancer cells) differed widely. Some studies included tumors other than PDAC, like neuroendocrine tumors or tumors of the papilla of Vater. This degree of variation is most likely true also for the samples representing normal tissues (commercially available RNA, normal tissue from resected pancreatic tumors or donor organs). Second, microdissection was applied by one group [51] while most studies were performed on whole tissue samples or cell lines. In cell lines, in vitro conditions may induce changes in gene expression that are not present in vivo. Pancreatic tumor specimens contain different cell types, including ductal, acinar, islet, inflammatory and nerve cells as well as fibrocytic elements. When whole tissues are used, the expression profiles represent both the variations in tumor and the adjacent non-neoplastic tissue. Third, different arrays and array technologies may lead to different gene expression results. As Kuo et al. [65] demonstrated, there can be poor correlation when the same samples are analyzed with two technologies (e.g., cDNA versus oligonucleotide microarrays). Fourth, statistical analysis and data mining procedures differed between the studies. Last, quite a few of the variations could well be due to individual reactions of the patients rather than being directly cancer-related. 
Table 3. Genes shown to be differentially transcribed in pancreatic tumors using microarray technology

\begin{tabular}{|c|c|c|c|c|c|c|c|c|c|c|c|c|c|c|c|}
\hline \multirow[t]{2}{*}{ UG_ID } & \multirow[t]{2}{*}{$\mathrm{a}$} & \multirow[t]{2}{*}{$\mathrm{b}$} & \multirow[t]{2}{*}{$\mathrm{c}$} & \multirow[t]{2}{*}{$\mathrm{d}$} & \multirow[t]{2}{*}{ e } & \multirow[t]{2}{*}{$\mathrm{f}$} & \multirow[t]{2}{*}{$\mathrm{g}$} & \multirow[t]{2}{*}{$\mathrm{h}$} & \multirow[t]{2}{*}{$\mathrm{i}$} & \multirow[t]{2}{*}{$\mathrm{j}$} & \multicolumn{2}{|c|}{ Counts } & \multirow[t]{2}{*}{ Acc } & \multirow[t]{2}{*}{ Name } & Symbol \\
\hline & & & & & & & & & & & $\mathrm{T}$ & $\mathrm{N}$ & & & \\
\hline Hs.2962 & $\mathrm{T}$ & $\mathrm{T}$ & $\mathrm{T}$ & $\mathrm{T}$ & $\mathrm{T}$ & & & & $\mathrm{T}$ & $\mathrm{T}$ & 7 & 0 & NM_005980 & S100 calcium-binding protein $\mathrm{P}$ & S100P \\
\hline Hs. 204238 & $\mathrm{~T}$ & $\mathrm{~T}$ & & & $\mathrm{~T}$ & $\mathrm{~T}$ & & & & $\mathrm{~T}$ & 5 & 0 & NM_005564 & Lipocalin 2 (oncogene $24 \mathrm{p} 3$ ) & LCN2 \\
\hline Hs. 287558 & & $\mathrm{~T}$ & $\mathrm{~T}$ & & $\mathrm{~T}$ & $\mathrm{~T}$ & & $\mathrm{~T}$ & & $\mathrm{~N}$ & 5 & 1 & NM_000700 & Annexin A1 & ANXA1 \\
\hline Hs. 54451 & $\mathrm{~T}$ & $\mathrm{~T}$ & $\mathrm{~T}$ & $\mathrm{~T}$ & $\mathrm{~T}$ & & & & & & 5 & 0 & NM_005562 & Laminin- $\gamma 2$ & LAMC2 \\
\hline Hs. 154036 & & $\mathrm{~T}$ & $\mathrm{~T}$ & $\mathrm{~T}$ & & & & $\mathrm{~T}$ & & & 4 & 0 & NM_003311 & $\begin{array}{l}\text { Pleckstrin homology-like domain, } \\
\text { family A, member } 2\end{array}$ & PHLDA2 \\
\hline Hs. 179657 & $\mathrm{~T}$ & & & $\mathrm{~T}$ & $\mathrm{~T}$ & $\mathrm{~T}$ & & & & & 4 & 0 & NM_002659 & Plasminogen activator, urokinase receptor & PLAUR \\
\hline Hs. 194691 & $\mathrm{~T}$ & $\mathrm{~T}$ & & & $\mathrm{~T}$ & & & $\mathrm{~T}$ & & & 4 & 0 & NM_003979 & Retinoic acid induced 3 & RAI3 \\
\hline Hs. 251754 & $\mathrm{~T}$ & & $\mathrm{~T}$ & & $\mathrm{~T}$ & & & $\mathrm{~T}$ & & & 4 & 0 & NM_003064 & $\begin{array}{l}\text { Secretory leukocyte protease inhibitor } \\
\text { (anti-leukoproteinase) }\end{array}$ & SLPI \\
\hline Hs. 408864 & & & $\mathrm{~T}$ & $\mathrm{~T}$ & $\mathrm{~T}$ & & & & & $\mathrm{~T}$ & 4 & 0 & NM_000574 & Decay-accelerating factor for complement ${ }^{1}$ & DAF \\
\hline Hs.417004 & & & $\mathrm{T}$ & $\mathrm{T}$ & $\mathrm{T}$ & $\mathrm{T}$ & & & & & 4 & 0 & NM_005620 & $\begin{array}{l}\text { S100 calcium-binding protein A11 } \\
\text { (calgizzarin) }\end{array}$ & S100A11 \\
\hline Hs. 82237 & $\mathrm{~T}$ & $\mathrm{~T}$ & & $\mathrm{~T}$ & & & & & $\mathrm{~T}$ & & 4 & 0 & NM_012101 & Tripartite motif-containing 29 & TRIM29 \\
\hline Hs. 82422 & $\mathrm{~T}$ & $\mathrm{~T}$ & $\mathrm{~T}$ & & $\mathrm{~T}$ & & & & & & 4 & 0 & NM_001747 & Capping protein (actin filament), gelsolin-like & CAPG \\
\hline Hs. 103707 & $\mathrm{~T}$ & & & & & & & $\mathrm{~T}$ & & $\mathrm{~T}$ & 3 & 0 & XM_039877 & $\begin{array}{l}\text { Mucin-5, subtypes A and C, } \\
\text { tracheobronchial/gastric }\end{array}$ & MUC5AC \\
\hline Hs. 111554 & $\mathrm{~T}$ & $\mathrm{~T}$ & & & $\mathrm{~T}$ & & & & & & 3 & 0 & NM_005737 & ADP-ribosylation factor-like 7 & ARL7 \\
\hline Hs. 1355 & & & $\mathrm{~T}$ & & $\mathrm{~T}$ & & & & & $\mathrm{~T}$ & 3 & 0 & NM_001910 & Cathepsin E & CTSE \\
\hline Hs. 139851 & $\mathrm{~T}$ & $\mathrm{~T}$ & & & $\mathrm{~T}$ & & & & & & 3 & 0 & $\mathrm{BC} 005256$ & Caveolin 2 & CAV2 \\
\hline Hs. 155419 & $\mathrm{~T}$ & & $\mathrm{~T}$ & $\mathrm{~T}$ & & & & & & & 3 & 0 & NM_001197 & BCL2-interacting killer (apoptosis-inducing) & $\mathrm{BIK}$ \\
\hline Hs. 156346 & $\mathrm{~T}$ & $\mathrm{~T}$ & $\mathrm{~T}$ & & & & & & & & 3 & 0 & NM_001067 & Topoisomerase (DNA) II $\alpha, 170 \mathrm{kDa}$ & TOP2A \\
\hline Hs.169902 & & & & $\mathrm{T}$ & $\mathrm{T}$ & & & & $\mathrm{T}$ & & 3 & 0 & NM_006516 & $\begin{array}{l}\text { Solute carrier family } 2 \text { (facilitated } \\
\text { glucose transporter), member } 1\end{array}$ & SLC2A1 \\
\hline Hs. 184510 & $\mathrm{~T}$ & & $\mathrm{~T}$ & $\mathrm{~T}$ & & & & & & & 3 & 0 & NM_006142 & Stratifin & SFN \\
\hline Hs. 220529 & $\mathrm{~T}$ & & & $\mathrm{~T}$ & $\mathrm{~T}$ & & & & & & 3 & 0 & NM_004363 & $\begin{array}{l}\text { Carcinoembryonic antigen-related } \\
\text { cell adhesion molecule } 5\end{array}$ & CEACAM5 \\
\hline Hs. 2442 & & & $\mathrm{~T}$ & & $\mathrm{~T}$ & & & $\mathrm{~T}$ & & & 3 & 0 & NM_003816 & $\begin{array}{l}\text { Disintegrin and metalloproteinase } \\
\text { domain } 9 \text { (meltrin- } \gamma)\end{array}$ & ADAM9 \\
\hline Hs. 2785 & $\mathrm{~T}$ & & & $\mathrm{~T}$ & $\mathrm{~T}$ & & & & & & 3 & 0 & NM_000422 & Keratin 17 & KRT17 \\
\hline Hs. 292738 & & & $\mathrm{~T}$ & & & $\mathrm{~T}$ & $\mathrm{~T}$ & & & & 3 & 0 & NM_001175 & Rho GDP dissociation inhibitor (GDI) $\beta$ & ARHGDIB \\
\hline Hs.2979 & $\mathrm{T}$ & & $\mathrm{T}$ & & & & & & & $\mathrm{T}$ & 3 & 0 & NM_005423 & Trefoil factor 2 (spasmolytic protein 1$)$ & TFF2 \\
\hline Hs. 301350 & & & $\mathrm{~T}$ & $\mathrm{~T}$ & $\mathrm{~T}$ & & & & & & 3 & 0 & NM_021910 & $\begin{array}{l}\text { FXYD domain containing ion transport } \\
\text { regulator } 3\end{array}$ & FXYD3 \\
\hline Hs. 309517 & & & $\mathrm{~T}$ & $\mathrm{~T}$ & $\mathrm{~T}$ & & & & & & 3 & 0 & NM_002276 & Keratin 19 & KRT19 \\
\hline Hs. 323733 & $\mathrm{~T}$ & $\mathrm{~T}$ & $\mathrm{~T}$ & & & & & & & & 3 & 0 & NM_004004 & $\begin{array}{l}\text { Gap junction protein, } \beta 2,26 \mathrm{kDa} \\
\text { (connexin } 26 \text { ) }\end{array}$ & GJB2 \\
\hline Hs. 348553 & $\mathrm{~T}$ & & & & $\mathrm{~T}$ & & & $\mathrm{~T}$ & & & 3 & 0 & AK027130 & Immortalization-upregulated protein & IMUP \\
\hline Hs. 362731 & & $\mathrm{~T}$ & & & $\mathrm{~T}$ & $\mathrm{~T}$ & & & & & 3 & 0 & NM_013451 & fer-1-like 3 , myoferlin (C. elegans) & FER1L3 \\
\hline Hs. 376874 & & & $\mathrm{~T}$ & $\mathrm{~T}$ & & & & & & $\mathrm{~T}$ & 3 & 0 & NM_002245 & Potassium channel, subfamily K, member 1 & $\mathrm{KCNK} 1$ \\
\hline Hs. 418138 & & & & & & & $\mathrm{~T}$ & & $\mathrm{~T}$ & $\mathrm{~T}$ & 3 & 0 & NM_002026 & Fibronectin 1 & FN1 \\
\hline Hs. 423190 & & & & & & & & $\mathrm{~T}$ & $\mathrm{~T}$ & $\mathrm{~T}$ & 3 & 0 & NM_001311 & Cysteine-rich protein 1 (intestinal) & CRIP1 \\
\hline Hs. 450230 & & & $\mathrm{~T}$ & $\mathrm{~T}$ & $\mathrm{~T}$ & & & & & & 3 & 0 & NM_000598 & Insulin-like growth factor-binding protein 3 & IGFBP3 \\
\hline Hs. 624 & $\mathrm{~T}$ & $\mathrm{~T}$ & $\mathrm{~T}$ & & & & & & & & 3 & 0 & NM_000584 & Interleukin- 8 & IL8 \\
\hline Hs. 83758 & & & $\mathrm{~T}$ & & & $\mathrm{~T}$ & & $\mathrm{~T}$ & & & 3 & 0 & NM_001827 & CDC28 protein kinase regulatory subunit 2 & CKS2 \\
\hline Hs. 85266 & & & $\mathrm{~T}$ & $\mathrm{~T}$ & & & & & $\mathrm{~T}$ & & 3 & 0 & NM_000213 & Integrin- $\beta 4$ & ITGB4 \\
\hline Hs. 112341 & $\mathrm{~T}$ & & $\mathrm{~T}$ & & & & & & & & 2 & 0 & NM_002638 & Protease inhibitor 3 , skin-derived (SKALP) & PI3 \\
\hline Hs. 115166 & $\mathrm{~T}$ & & & & $\mathrm{~T}$ & & & & & & 2 & 0 & NM_144777 & Sciellin & SCEL \\
\hline Hs. 118400 & $\mathrm{~T}$ & $\mathrm{~T}$ & & & & & & & & & 2 & 0 & NM_003088 & $\begin{array}{l}\text { Fascin homolog } 1 \text {, actin-bundling protein } \\
\text { (Strongylocentrotus purpuratus) }\end{array}$ & FSCN1 \\
\hline Hs. 126222 & & & & & $\mathrm{~T}$ & & & $\mathrm{~T}$ & & & 2 & 0 & NM_005717 & $\begin{array}{l}\text { Actin-related protein } 2 / 3 \text { complex, } \\
\text { subunit5, } 16 \mathrm{kDa}\end{array}$ & ARPC5 \\
\hline Hs. 127799 & & $\mathrm{~T}$ & $\mathrm{~T}$ & & & & & & & & 2 & 0 & NM_001165 & Baculoviral IAP repeat-containing 3 & BIRC3 \\
\hline Hs. 128453 & & & $\mathrm{~T}$ & & & & & & & $\mathrm{~T}$ & 2 & 0 & NM_001463 & Frizzled-related protein & FRZB \\
\hline Hs. 136348 & & $\mathrm{~T}$ & & & & & & & $\mathrm{~T}$ & & 2 & 0 & NM_006475 & Osteoblast-specific factor-2 (fasciclin-I-like) & OSF-2 \\
\hline Hs.139389 & & & $\mathrm{T}$ & $\mathrm{T}$ & & & & & & & 2 & 0 & NM_001323 & Cystatin E/M & CST6 \\
\hline Hs. 1600 & & & & & $\mathrm{~T}$ & & & $\mathrm{~T}$ & & & 2 & 0 & NM_012073 & Chaperonin-containing TCP1, subunit $5(\varepsilon)$ & CCT5 \\
\hline Hs. 172928 & & & & & & & & & $\mathrm{~T}$ & $\mathrm{~T}$ & 2 & 0 & NM_000088 & Collagen type I, $\alpha 1$ & COL1A1 \\
\hline Hs. 179729 & $\mathrm{~T}$ & & $\mathrm{~T}$ & & & & & & & & 2 & 0 & NM_000493 & $\begin{array}{l}\text { Collagen type } \mathrm{X}, \alpha 1 \text { (Schmid } \\
\text { metaphyseal chondrodysplasia) }\end{array}$ & COL10A1 \\
\hline Hs. 180909 & & & $\mathrm{~T}$ & & $\mathrm{~T}$ & & & & & & 2 & 0 & NM_002574 & Peroxiredoxin 1 & PRDX1 \\
\hline Hs. 180919 & & & $\mathrm{~T}$ & & & & & & & $\mathrm{~T}$ & 2 & 0 & NM_002166 & $\begin{array}{l}\text { Inhibitor of DNA-binding } 2 \text {, dominant } \\
\text { negative helix-loop-helix protein }\end{array}$ & ID2 \\
\hline Hs. 191842 & & & $\mathrm{~T}$ & $\mathrm{~T}$ & & & & & & $\mathrm{~N}$ & 2 & 1 & NM_001793 & Cadherin 3 , type 1, P-cadherin (placental) & $\mathrm{CDH} 3$ \\
\hline Hs. 198281 & & & & $\mathrm{~T}$ & & & & & $\mathrm{~T}$ & $\mathrm{~N}$ & 2 & 1 & NM_182470 & Pyruvate kinase, muscle & PKM2 \\
\hline Hs. 211573 & & & $\mathrm{~T}$ & $\mathrm{~T}$ & & & & & & & 2 & 0 & NM_005529 & Heparan sulfate proteoglycan 2 (perlecan) & HSPG2 \\
\hline
\end{tabular}


Table 3 (continued)

\begin{tabular}{|c|c|c|c|c|c|c|c|c|c|c|c|c|c|c|c|}
\hline \multirow[t]{2}{*}{ UG_ID } & \multirow[t]{2}{*}{ a } & \multirow[t]{2}{*}{$\mathrm{b}$} & \multirow[t]{2}{*}{$\mathrm{c}$} & \multirow[t]{2}{*}{$\mathrm{d}$} & \multirow[t]{2}{*}{$\mathrm{e}$} & \multirow[t]{2}{*}{$\mathrm{f}$} & \multirow[t]{2}{*}{$\mathrm{g}$} & \multirow[t]{2}{*}{$\mathrm{h}$} & \multirow[t]{2}{*}{$\mathrm{i}$} & \multirow[t]{2}{*}{$\mathrm{j}$} & \multicolumn{2}{|c|}{ Counts } & \multirow[t]{2}{*}{ Acc } & \multirow[t]{2}{*}{ Name } & \multirow[t]{2}{*}{ Symbol } \\
\hline & & & & & & & & & & & $\mathrm{T}$ & $\mathrm{N}$ & & & \\
\hline Hs. 21486 & & & $\mathrm{~T}$ & $\mathrm{~T}$ & & & & & & & 2 & 0 & NM_007315 & $\begin{array}{l}\text { Signal transducer and activator of } \\
\text { transcription } 1,91 \mathrm{kDa}\end{array}$ & STAT1 \\
\hline Hs. 21858 & & & & & & $\mathrm{~T}$ & $\mathrm{~T}$ & & & & 2 & 0 & NM_006216 & $\begin{array}{l}\text { Serine (or cysteine) proteinase } \\
\text { inhibitor, clade } \mathrm{E}^{2}\end{array}$ & SERPINE2 \\
\hline Hs. 223025 & & & $\mathrm{~T}$ & & & & $\mathrm{~T}$ & & & & 2 & 0 & NM_006868 & RAB31, member RAS oncogene family & RAB31 \\
\hline Hs. 226391 & & & & & $\mathrm{~T}$ & & & & $\mathrm{~T}$ & & 2 & 0 & NM_006408 & $\begin{array}{l}\text { Anterior gradient- } 2 \text { homolog } \\
\text { (Xenopus laevis) }\end{array}$ & AGR2 \\
\hline Hs. 227806 & $\mathrm{~T}$ & $\mathrm{~T}$ & & & & & & & & & 2 & 0 & NM_170692 & RAS protein activator-like 2 & RASAL2 \\
\hline Hs.22941 & $\mathrm{T}$ & $\mathrm{T}$ & & & & & & & & & 2 & 0 & NM_020792 & KIAA 1363 protein & KIAA1363 \\
\hline Hs. 232115 & & $\mathrm{~T}$ & & & & & $\mathrm{~T}$ & & & & 2 & 0 & NM_000089 & Collagen type-I, $\alpha 2$ & COL1A2 \\
\hline Hs. 235782 & $\mathrm{~T}$ & $\mathrm{~T}$ & & & & & & & & & 2 & 0 & NM_016354 & $\begin{array}{l}\text { Solute carrier organic anion transporter } \\
\text { family, member } 4 \mathrm{~A} 1\end{array}$ & SLCO4A1 \\
\hline Hs. 23881 & $\mathrm{~T}$ & & & $\mathrm{~T}$ & & & & & & & 2 & 0 & NM_005556 & Keratin 7 & KRT7 \\
\hline Hs. 241579 & $\mathrm{~T}$ & $\mathrm{~T}$ & & & & & & & & & 2 & 0 & NM_001235 & $\begin{array}{l}\text { Serine (or cysteine) proteinase inhibitor, } \\
\text { clade } \mathrm{H}^{3}\end{array}$ & SERPINH1 \\
\hline Hs.2499 & & $\mathrm{T}$ & & $\mathrm{T}$ & & & & & & & 2 & 0 & NM_002741 & Protein kinase C-like 1 & PRKCL1 \\
\hline Hs. 250641 & & & $\mathrm{~T}$ & & $\mathrm{~T}$ & & & & & & 2 & 0 & NM_003290 & Tropomyosin 4 & TPM4 \\
\hline Hs. 250822 & & & & & & $\mathrm{~T}$ & & $\mathrm{~T}$ & & & 2 & 0 & NM_003600 & Serine/threonine kinase 6 & STK6 \\
\hline Hs. 25338 & & $\mathrm{~T}$ & & & $\mathrm{~T}$ & & & & & & 2 & 0 & NM_007173 & Protease, serine, 23 & SPUVE \\
\hline Hs. 265829 & & & & $\mathrm{~T}$ & $\mathrm{~T}$ & & & & & $\mathrm{~N}$ & 2 & 1 & NM_002204 & $\begin{array}{l}\text { Integrin- } \alpha 3 \text { (antigen CD } 49 C, \alpha 3 \text { subunit of } \\
\text { VLA-3 receptor) }\end{array}$ & ITGA3 \\
\hline Hs. 268571 & & $\mathrm{~T}$ & $\mathrm{~T}$ & & & & & & & & 2 & 0 & NM_001645 & Apolipoprotein C-I & APOC1 \\
\hline Hs. 272822 & $\mathrm{~T}$ & & & & $\mathrm{~T}$ & & & & & & 2 & 0 & NM_003707 & RuvB-like 1 (E. coli) & RUVBL1 \\
\hline Hs. 275243 & & & & $\mathrm{~T}$ & & & & & $\mathrm{~T}$ & & 2 & 0 & NM_014624 & S100 calcium-binding protein A6 (calcyclin) & S100A6 \\
\hline Hs. 278613 & & & & $\mathrm{~T}$ & & & & $\mathrm{~T}$ & & & 2 & 0 & NM_005532 & Interferon- $\alpha$-inducible protein 27 & IFI27 \\
\hline Hs. 278896 & & & $\mathrm{~T}$ & $\mathrm{~T}$ & & & & & & & 2 & 0 & NM_019075 & $\begin{array}{l}\text { UDP glycosyltransferase-1 family, } \\
\text { polypeptide A10 }\end{array}$ & UGT1A10 \\
\hline Hs. 279651 & $\mathrm{~T}$ & & $\mathrm{~T}$ & & & & & & & & 2 & 0 & NM_006533 & Melanoma inhibitory activity & MIA \\
\hline Hs. 283565 & $\mathrm{~T}$ & & & & & $\mathrm{~T}$ & & & & & 2 & 0 & NM_005438 & FOS-like antigen 1 & FOSL1 \\
\hline Hs. 334562 & $\mathrm{~T}$ & & & & $\mathrm{~T}$ & & & & & & 2 & 0 & NM_001786 & Cell division cycle $2, \mathrm{G} 1$ to $\mathrm{S}$ and $\mathrm{G} 2$ to $\mathrm{M}$ & $\mathrm{CDC} 2$ \\
\hline Hs. 348935 & & & $\mathrm{~N}$ & & & & $\mathrm{~T}$ & & $\mathrm{~T}$ & & 2 & 1 & NM_020070 & Immunoglobulin- $\lambda$-like polypeptide 1 & IGLL1 \\
\hline Hs. 352018 & & & $\mathrm{~T}$ & $\mathrm{~T}$ & & & & & & & 2 & 0 & NM_000593 & $\begin{array}{l}\text { Transporter } 1 \text {, ATP-binding cassette, } \\
\text { subfamily B (MDR/TAP) }\end{array}$ & TAP1 \\
\hline Hs. 3628 & $\mathrm{~T}$ & $\mathrm{~T}$ & & & & & & & & & 2 & 0 & NM_145686 & $\begin{array}{l}\text { Mitogen-activated protein kinase kinase } \\
\text { kinase kinase } 4\end{array}$ & MAP4K4 \\
\hline Hs. 387579 & & & $\mathrm{~T}$ & & $\mathrm{~T}$ & & & & & & 2 & 0 & NM_001769 & CD9 antigen (p24) & CD9 \\
\hline Hs. 387725 & & & & $\mathrm{~T}$ & $\mathrm{~T}$ & & & & & & 2 & 0 & NM_002203 & $\begin{array}{l}\text { Integrin- } \alpha 2 \text { (CD49B, } \alpha 2 \text { subunit of } \\
\text { VLA-2 receptor) }\end{array}$ & ITGA2 \\
\hline Hs.38972 & $\mathrm{T}$ & & & & $\mathrm{T}$ & & & & & & 2 & 0 & NM_005727 & Tetraspan 1 & TSPAN-1 \\
\hline Hs. 406475 & & & & & & & $\mathrm{~T}$ & & $\mathrm{~T}$ & & 2 & 0 & NM_002345 & Lumican & LUM \\
\hline Hs. 406515 & & & $\mathrm{~T}$ & $\mathrm{~T}$ & & & & & & & 2 & 0 & NM_000903 & $\mathrm{NAD}(\mathrm{P}) \mathrm{H}$ dehydrogenase, quinone 1 & NQO1 \\
\hline Hs.411701 & & & & & $\mathrm{T}$ & & & & & $\mathrm{T}$ & 2 & 0 & NM_194327 & $\begin{array}{l}\text { Lectin, galactoside-binding, soluble, } 3 \\
\text { (galectin 3) }\end{array}$ & LGALS3 \\
\hline Hs.411958 & & & $\mathrm{T}$ & & $\mathrm{T}$ & & & & & & 2 & 0 & NM_018950 & Major histocompatibility complex, class I, F & HLA-F \\
\hline Hs. 419776 & & $\mathrm{~T}$ & & & $\mathrm{~T}$ & & & & & & 2 & 0 & NM_139207 & Nucleosome assembly protein-1-like 1 & NAP1L1 \\
\hline Hs. 434488 & & $\mathrm{~T}$ & & & & & $\mathrm{~T}$ & & & & 2 & 0 & NM_004385 & Chondroitin sulfate proteoglycan 2 (versican) & CSPG2 \\
\hline Hs. 436718 & & & & $\mathrm{~T}$ & & $\mathrm{~T}$ & & & & & 2 & 0 & NM_002483 & $\begin{array}{l}\text { Carcinoembryonic antigen-related cell } \\
\text { adhesion molecule } 6^{4}\end{array}$ & CEACAM6 \\
\hline Hs. 436983 & & & $\mathrm{~T}$ & $\mathrm{~T}$ & & & & & & & 2 & 0 & NM_000228 & Laminin- $\beta 3$ & LAMB3 \\
\hline Hs. 445226 & & & $\mathrm{~T}$ & $\mathrm{~T}$ & & & & & & & 2 & 0 & NM_004240 & Thyroid hormone receptor interactor 10 & TRIP10 \\
\hline Hs. 512682 & & & $\mathrm{~T}$ & $\mathrm{~T}$ & & & & & & & 2 & 0 & NM_001712 & $\begin{array}{l}\text { Carcinoembryonic antigen-related cell } \\
\text { adhesion molecule } 1^{5}\end{array}$ & CEACAM1 \\
\hline Hs. 512708 & & $\mathrm{~T}$ & & & $\mathrm{~T}$ & & & & & & 2 & 0 & NM_004613 & Transglutaminase $2^{6}$ & TGM2 \\
\hline Hs. 512711 & & & & & $\mathrm{~T}$ & & & & & $\mathrm{~T}$ & 2 & 0 & NM_000365 & Triosephosphate isomerase 1 & TPI1 \\
\hline Hs. 55279 & & & & $\mathrm{~T}$ & & & & & $\mathrm{~T}$ & & 2 & 0 & NM_002639 & $\begin{array}{l}\text { Serine (or cysteine) proteinase inhibitor, } \\
\text { clade B (ovalbumin), member } 5\end{array}$ & SERPINB5 \\
\hline Hs.56319 & & & $\mathrm{T}$ & $\mathrm{T}$ & & & & & & & 2 & 0 & NM_001899 & Cystatin S & CST4 \\
\hline Hs. 727 & $\mathrm{~T}$ & & & $\mathrm{~T}$ & & & & & & & 2 & 0 & NM_002192 & $\begin{array}{l}\text { Inhibin- } \beta \mathrm{A} \text { (activin } \mathrm{A} \text {, activin } \mathrm{AB} \\
\alpha \text {-polypeptide) }\end{array}$ & INHBA \\
\hline Hs. 72925 & & & $\mathrm{~T}$ & $\mathrm{~T}$ & & & & & & & 2 & 0 & NM_003475 & Chromosome-11 open reading frame 13 & C11orf13 \\
\hline Hs. 75318 & & & & $\mathrm{~T}$ & $\mathrm{~T}$ & & & & & & 2 & 0 & NM_006000 & Tubulin- $\alpha 1$ (testis specific) & TUBA1 \\
\hline Hs. 75360 & & & $\mathrm{~T}$ & & & & & & & $\mathrm{~T}$ & 2 & 0 & NM_001873 & Carboxypeptidase E & CPE \\
\hline Hs. 77274 & $\mathrm{~T}$ & & & & & & & & $\mathrm{~T}$ & & 2 & 0 & NM_002658 & Plasminogen activator, urokinase & PLAU \\
\hline Hs. 77348 & & & $\mathrm{~T}$ & & $\mathrm{~T}$ & & & & & & 2 & 0 & NM_000860 & $\begin{array}{l}\text { Hydroxyprostaglandin dehydrogenase } 15 \\
\text { (NAD) }\end{array}$ & HPGD \\
\hline Hs. 77515 & & & $\mathrm{~T}$ & $\mathrm{~T}$ & & & & & & & 2 & 0 & NM_002224 & Inositol 1,4,5-triphosphate receptor, type 3 & ITPR3 \\
\hline
\end{tabular}


Table 3 (continued)

\begin{tabular}{|c|c|c|c|c|c|c|c|c|c|c|c|c|c|c|}
\hline \multirow[t]{2}{*}{ UG_ID } & \multirow[t]{2}{*}{$\mathrm{a}$} & \multirow[t]{2}{*}{$\mathrm{b}$} & \multirow[t]{2}{*}{$\mathrm{c}$} & \multirow[t]{2}{*}{$\mathrm{d}$} & \multirow[t]{2}{*}{ e } & \multirow[t]{2}{*}{$\mathrm{f}$} & \multirow[t]{2}{*}{$\mathrm{g}$} & \multirow[t]{2}{*}{$\mathrm{h}$} & \multirow[t]{2}{*}{$\mathrm{i}$} & \multirow[t]{2}{*}{$\mathrm{j}$} & Counts & \multirow[t]{2}{*}{ Acc } & \multirow[t]{2}{*}{ Name } & \multirow[t]{2}{*}{ Symbol } \\
\hline & & & & & & & & & & & $\mathrm{N}$ & & & \\
\hline Hs.79033 & & & $\mathrm{T}$ & & & & & & & $\mathrm{T}$ & 0 & NM_012413 & $\begin{array}{l}\text { Glutaminyl-peptide cyclotransferase } \\
\text { (glutaminyl cyclase) }\end{array}$ & QPCT \\
\hline Hs.79440 & $\mathrm{T}$ & $\mathrm{T}$ & & & & & & & & & 0 & NM_006547 & IGF-II mRNA-binding protein 3 & IMP-3 \\
\hline Hs. 82101 & $\mathrm{~T}$ & $\mathrm{~T}$ & & & & & & & & & 0 & NM_007350 & $\begin{array}{l}\text { Pleckstrin homology-like domain, } \\
\text { family A, member } 1\end{array}$ & PHLDA1 \\
\hline Hs. 82109 & & & $\mathrm{~T}$ & & $\mathrm{~T}$ & & & & & & 0 & NM_002997 & Syndecan 1 & $\mathrm{SDC} 1$ \\
\hline Hs. 82961 & & & & & & & & & $\mathrm{~T}$ & $\mathrm{~T}$ & 0 & NM_003226 & Trefoil factor 3 (intestinal) & TFF3 \\
\hline Hs. 83450 & & & $\mathrm{~T}$ & $\mathrm{~T}$ & & & & & & $\mathrm{~N}$ & 1 & NM_198129 & Laminin- $\alpha 3$ & LAMA3 \\
\hline Hs. 83753 & & & & & $\mathrm{~T}$ & $\mathrm{~T}$ & & & & & 0 & NM_003091 & $\begin{array}{l}\text { Small nuclear ribonucleoprotein } \\
\text { polypeptides B and B1 }\end{array}$ & SNRPB \\
\hline Hs. 85226 & & & $\mathrm{~T}$ & & $\mathrm{~T}$ & & & & & & 0 & NM_000235 & $\begin{array}{l}\text { Lipase A, lysosomal acid, cholesterol } \\
\text { esterase (Wolman disease) }\end{array}$ & LIPA \\
\hline Hs. 86947 & & & $\mathrm{~T}$ & $\mathrm{~T}$ & & & & & & & 0 & NM_001109 & Disintegrin and metalloproteinase domain 8 & ADAM8 \\
\hline Hs. 87268 & & & $\mathrm{~T}$ & $\mathrm{~T}$ & & & & & & $\mathrm{~N}$ & 1 & NM_001630 & Annexin A8 & ANXA8 \\
\hline Hs. 89434 & $\mathrm{~T}$ & $\mathrm{~T}$ & & & & & & & & & 0 & NM_080881 & Drebrin 1 & DBN1 \\
\hline Hs. 98428 & $\mathrm{~T}$ & & & & $\mathrm{~T}$ & & & & & & 0 & NM_156036 & Homeo box B6 & HOXB6 \\
\hline Hs. 123107 & & & $\mathrm{~N}$ & & & & & $\mathrm{~N}$ & $\mathrm{~N}$ & & 3 & NM_002257 & Kallikrein 1 , renal/pancreas/salivary & KLK1 \\
\hline Hs.199695 & & & $\mathrm{N}$ & & & $\mathrm{N}$ & & & $\mathrm{N}$ & & 3 & NM_014573 & Hypothetical protein MAC30 & MAC 30 \\
\hline Hs. 26126 & & & $\mathrm{~N}$ & & & $\mathrm{~N}$ & & & $\mathrm{~N}$ & & 3 & NM_182848 & Claudin 10 & CLDN10 \\
\hline Hs. 375108 & & & & & & $\mathrm{~N}$ & $\mathrm{~N}$ & $\mathrm{~N}$ & & & 3 & NM_013230 & $\begin{array}{l}\text { CD24 antigen (small cell lung carcinoma } \\
\text { cluster } 4 \text { antigen) }\end{array}$ & $\mathrm{CD} 24$ \\
\hline Hs.409223 & & & $\mathrm{N}$ & & & $\mathrm{N}$ & & & $\mathrm{N}$ & & 3 & NM_006280 & $\begin{array}{l}\text { Signal sequence receptor, } \delta \\
\text { (translocon-associated protein } \delta \text { ) }\end{array}$ & SSR4 \\
\hline Hs. 423 & & & $\mathrm{~N}$ & & & & & $\mathrm{~N}$ & $\mathrm{~N}$ & & 3 & NM_138938 & Pancreatitis-associated protein & PAP \\
\hline Hs.75335 & & & $\mathrm{N}$ & & & & $\mathrm{N}$ & & $\mathrm{N}$ & & 3 & NM_001482 & $\begin{array}{l}\text { Glycine amidinotransferase } \\
\text { ( } L \text {-arginine:glycine amidinotransferase) }\end{array}$ & GATM \\
\hline Hs.992 & & & $\mathrm{N}$ & & & & & $\mathrm{N}$ & $\mathrm{N}$ & & 3 & NM_000928 & Phospholipase A2, group IB (pancreas) & PLA2G1B \\
\hline Hs. 25647 & & & & & & $\mathrm{~N}$ & & $\mathrm{~N}$ & & $\mathrm{~T}$ & 2 & NM_005252 & $\begin{array}{l}\mathrm{v} \text {-fos FBJ murine osteosarcoma viral } \\
\text { oncogene homolog }\end{array}$ & FOS \\
\hline Hs. 107 & & & $\mathrm{~N}$ & & & & & & $\mathrm{~N}$ & & 2 & NM_004467 & Fibrinogen-like 1 & FGL1 \\
\hline Hs. 1239 & & & $\mathrm{~N}$ & & & & & & $\mathrm{~N}$ & & 2 & NM_001150 & Alanyl (membrane) aminopeptidase ${ }^{7}$ & ANPEP \\
\hline Hs. 1340 & & & $\mathrm{~N}$ & & & & & $\mathrm{~N}$ & & & 2 & NM_001832 & Colipase, pancreatic & CLPS \\
\hline Hs. 169234 & & & $\mathrm{~N}$ & & & & & & $\mathrm{~N}$ & & 2 & NM_015849 & Pancreatic elastase IIB & ELA2B \\
\hline Hs. 169900 & & & $\mathrm{~N}$ & & & & & & $\mathrm{~N}$ & & 2 & NM_003819 & $\begin{array}{l}\text { Poly(A)-binding protein, cytoplasmic } 4 \\
\text { (inducible form) }\end{array}$ & PABPC4 \\
\hline Hs. 181300 & & & $\mathrm{~N}$ & & & & & & $\mathrm{~N}$ & & 2 & NM_005065 & Sel-1 suppressor of lin-12-like (C. elegans) & SEL1L \\
\hline Hs. 2879 & & & $\mathrm{~N}$ & & & & & $\mathrm{~N}$ & & & 2 & NM_001868 & Carboxypeptidase A1 (pancreatic) & CPA1 \\
\hline Hs.388004 & & & $\mathrm{N}$ & & & & $\mathrm{N}$ & & & & 2 & NM_000687 & S-adenosylhomocysteine hydrolase & AHCY \\
\hline Hs. 407856 & & & $\mathrm{~N}$ & & & & & $\mathrm{~N}$ & & & 2 & NM_003122 & Serine protease inhibitor, Kazal type 1 & SPINK1 \\
\hline Hs. 410578 & & & $\mathrm{~N}$ & & & & $\mathrm{~N}$ & & & & 2 & NM_000918 & $\begin{array}{l}\text { Procollagen-proline, 2-oxoglutarate } \\
\text { 4-dioxygenase }{ }^{8}\end{array}$ & $\mathrm{P} 4 \mathrm{HB}$ \\
\hline Hs. 422542 & & & $\mathrm{~N}$ & & & & & $\mathrm{~N}$ & & & 2 & NM_004132 & Hyaluronan-binding protein 2 & HABP2 \\
\hline Hs.433391 & & & $\mathrm{N}$ & & & & & $\mathrm{N}$ & & & 2 & NM_005950 & Metallothionein $1 \mathrm{G}$ & MT1G \\
\hline Hs. 433750 & & & $\mathrm{~N}$ & & & & & & & $\mathrm{~N}$ & 2 & NM_182917 & Eukaryotic translation initiation factor $4 \gamma, 1$ & EIF4G1 \\
\hline Hs. 433797 & & & $\mathrm{~N}$ & & & & & & $\mathrm{~N}$ & & 2 & NM_002885 & RAP1, GTPase-activating protein 1 & RAP1GA1 \\
\hline Hs.435699 & & & $\mathrm{N}$ & & & & & & $\mathrm{N}$ & & 2 & NM_002771 & Protease, serine, 3 (mesotrypsin) & PRSS3 \\
\hline Hs. 436042 & & & $\mathrm{~N}$ & & & & & $\mathrm{~N}$ & & & 2 & NM_000609 & $\begin{array}{l}\text { Chemokine (C-X-C motif) ligand } 12 \\
\text { (stromal cell-derived factor 1) }\end{array}$ & CXCL12 \\
\hline Hs. 437638 & & & $\mathrm{~N}$ & & & & & & $\mathrm{~N}$ & & 2 & NM_005080 & X-box binding protein 1 & XBP1 \\
\hline Hs.444159 & & & & & & & & $\mathrm{N}$ & $\mathrm{N}$ & & 2 & NM_003627 & Solute carrier family 43 , member 1 & SLC43A1 \\
\hline Hs.74502 & & & $\mathrm{N}$ & & & & & $\mathrm{N}$ & & & 2 & NM_001906 & Chymotrypsinogen B1 & CTRB1 \\
\hline Hs. 75462 & & & & & & & $\mathrm{~N}$ & & $\mathrm{~N}$ & & 2 & NM_006763 & BTG family, member 2 & BTG2 \\
\hline Hs.79361 & & & $\mathrm{N}$ & & & & & & $\mathrm{N}$ & & 2 & NM_002774 & Kallikrein 6 (neurosin, zyme) & KLK6 \\
\hline Hs.79428 & & & $\mathrm{N}$ & & & & & & $\mathrm{N}$ & & 2 & NM_004052 & $\begin{array}{l}\text { BCL2/adenovirus E1B } 19 \mathrm{kDa} \text { interacting } \\
\text { protein } 3\end{array}$ & BNIP3 \\
\hline Hs. 80206 & & & $\mathrm{~N}$ & & & & & & & $\mathrm{~N}$ & 2 & NM_000402 & Glucose-6-phosphate dehydrogenase & G6PD \\
\hline Hs. 81131 & & & $\mathrm{~N}$ & & & & & & $\mathrm{~N}$ & & 2 & NM_000156 & Guanidinoacetate N-methyltransferase & GAMT \\
\hline $1 \mathrm{CD} 55$, & & bloo & & & & & & & & & & Prolir & oxylase), $\beta$-polypeptide (protein disulfide & isomerase; thy- \\
\hline 2 Nexin, & & & & & & & & & & & & & binding & \\
\hline 3 Heat sh & $\mathrm{k} \mathrm{pr}$ & ein & 7, me & nber & 1, coll & lagen & bindi & ag pro & tein 1 & & & $\mathrm{a}=\mathrm{Iacol}$ & io-Donahue CR2003 [54]; b = Iacobuzio-Do & ahue AJP2002 \\
\hline $4 \quad$ Non-sp & fic & oss-r & actin & anti & & & & & & & & [47]; $\mathrm{c}=$ Fries & CMLS2003 [53]; $\mathrm{d}=$ Logsdon CR2003 [50] & $\mathrm{e}=$ Iacobuzio- \\
\hline 5 Biliary & cop & tein & & & & & & & & & & Donahue AJP & 003 [49]; f = Han CR2002 [46]; g = Tan WJ & $2003[48] ; \mathrm{h}=$ \\
\hline 6 C polyp & tide & rote & n-glu & $a_{1}$ & e- $\gamma$-glt & utamy & ylt & feras & & & & Grützmann V & 2003 [51]; i $=$ Crnogorac-Jurcevic JP2003 & 52 ]; $j=$ Terris \\
\hline 7 Aminor & otid & & & & tidase & $\mathrm{M}$ & & osoma & al a & hinope & eptidase, & $\begin{array}{l}\text { AJP2002 [55] } \\
\text { mal tissue. }\end{array}$ & $T=$ overexpressed in tumor tissue $; \mathrm{N}=$ overe & pressed in nor- \\
\hline
\end{tabular}


The majority of the 148 genes $(n=115)$ were found to be upregulated in pancreatic tumors. One gene, S100 calcium-binding protein $\mathrm{P}$, was upregulated in 7 of the 10 studies. Three genes, among them annexin-A1, lipocalin- 2 and laminin- $\gamma 2$, were upregulated in 5 studies. Eight genes, including gelsolin-like protein, S100 calcium-binding protein A11, plasminogen activator, urokinase receptor and retinoic acid induced 3, were overexpressed in 4 studies. Three of 10 was scored by 25 genes, among them ADAM9. Its expression was very recently found to be an independent marker of shortened survival after curative resection of PDAC [66]. The majority of genes (in total 78) were upregulated in 2 studies. Among the genes that were overexpressed in PDAC, 9 genes including keratin-7 [67], stratifin [68] and CD55 [69] had been previously implicated in PDAC. These genes, which have also been identified by other profiling methods, confirm the validity of microarray-based expression profiling. Moreover, 14 of the upregulated genes were known from microarray analyses on other cancers. This includes versican (overexpressed in malignant melanomas) [70], insulin-like growth factor-binding protein-3 (overexpressed in nonsmall cell lung cancer and breast cancer) $[71,72]$ and carcinoembryonic antigen-related cell adhesion molecule-6 (CEACAM6; overexpressed in colorectal carcinomas) [73]. These genes might play an important role in PDAC, too. The remaining 13 genes listed in table 3 have not before been implicated to be involved in carcinogenesis.

Only 33 genes were found to be downregulated in pancreatic tumors in 2 or 3 of the 10 publications, respectively, among them CD24 antigen and V-fos FBJ murine osteosarcoma viral oncogene homolog. These two genes had not been described to be of relevance in PDAC before. Interestingly, however, CD24 was found to be an independent prognostic marker in non-small cell lung cancer patients [74]. Several genes, among them nucleosome assembly protein-1-like 1 (NAP1L1), showed discrepant results. In two studies, NAP1L1 was described as upregulated [47, 50], whereas a downregulated status was detected with microdissected material [51].

\section{Microarray Studies for Answering Clinical Questions}

Microarray technology has been proven to be feasible in pancreatic tumors. Many novel candidate genes emerged from the initial studies. On the other hand, so far the expression profiles have not been proven to correlate with individual cancer stages, grading and TMN classifi- cation. Also, molecular differences between long- and short-time survivors have not been detected. Most probably, however, this is mainly due to the small number of samples in the studies mentioned above. New investigations are under way in several laboratories, including our own, and will eventually provide the information necessary. Already, the discrimination power of such analyses was found to be sufficient to define new tumor entities on the basis of their transcript profile [75].

The possibility of individualized medicine, the molecular correlation between responders and non-responders to adjuvant or neoadjuvant therapy, for example, is one of the aims in this line of research. This, however, requires carefully designed prospective profiling studies on hundreds of patients, possibly focusing the analysis on microdissected cells from normal and matched cancerous pancreatic tissues. Moreover, the approach only analyzes differences in the expression level of the genes, but not the activity of proteins. Therefore, interesting candidate genes have to be validated on the level of protein activity.

\section{Conclusions and Perspectives}

Due to the human genome project, sequence information of the entire human genome is available. In the form of DNA microarrays, it can be utilized for global analyses of gene expression. As opposed to earlier approaches, no well-defined working hypothesis is required in this methodology. It is a matter of comparing the transcript levels between different tissues, or between healthy and diseased tissue of the same kind. This approach exhibits both advantages and weak points. A major advantage is the fact that the analysis of gene expression is a totally unprejudiced process. No desires, assumptions or theories of the experimenter are incorporated in the investigations. Analysis and initial interpretation should be based purely on statistical means. Also, no pre-selection of genes is taking place. One of the major drawbacks is the fact that frequently the interpretation of the data is not immediately feasible. Further, for the lack of a hypothesis, a reasonably large amount of information has to be attained before a statistically significant conclusion can be phrased.

In conclusion, microarray-based transcript analyses have broadened our understanding of tumor biology. These data will influence diagnostic and therapeutic strategies for the treatment PDAC and other tumors. With the great progress made in the handling and analysis of microarrays, it can be assumed that more insights will 
soon be gained into the fundamental changes occurring within a cancer cell. In future, and really not too far ahead, microarray technology will be broadly introduced into clinical practice. The discovery of novel therapeutically useful genes and diagnostic markers will fuel medical progress and lead eventually to novel drugs and diagnostic strategies.

\section{Acknowledgements}

We would like to thank our colleagues in many institutions for their collaboration and useful discussions. We are grateful to Grit Faulmann for critical reading of the manuscript, as well as Alfred Neumann whose comments were always appreciated. Work in the authors' laboratories was supported by the Deutsche Krebshilfe (702937-SaI, 10-1473-Gr2), the German Federal Ministry of Education and Research via the National Genome Research Network (NGFN; 01 GR 0101), the European Union (QLG1-CT-2002-01196) and the Ministry of Science and Art of Baden-Württemberg.

\section{References}

1 Johansson KA, Grapin-Botton A: Development and diseases of the pancreas. Clin Genet 2002;62:14-23.

2 Becker WJN: Krebsatlas der Bundesrepublik Deutschland - Atlas of Cancer Mortality in Germany: 1981-1990. Berlin, Springer, 1997.

3 Hruban RH, van Mansfeld AD, Offerhaus GJ, van Weering DH, Allison DC, Goodman SN, Kensler TW, Bose KK, Cameron JL, Bos JL: $\mathrm{K}$-ras oncogene activation in adenocarcinoma of the human pancreas. A study of 82 carcinomas using a combination of mutant-enriched polymerase chain reaction analysis and allelespecific oligonucleotide hybridization. Am J Pathol 1993;143:545-554.

4 Almoguera C, Shibata D, Forrester K, Martin J, Arnheim N, Perucho M: Most human carcinomas of the exocrine pancreas contain mutant c-K-ras genes. Cell 1988;53:549-554.

5 Caldas C, Kern SE: K-ras mutation and pancreatic adenocarcinoma. Int J Pancreatol 1995; 18:1-6.

6 Terhune PG, Phifer DM, Tosteson TD, Longnecker DS: K-ras mutation in focal proliferative lesions of human pancreas. Cancer Epidemiol Biomarkers Prev 1998;7:515-521.

7 Caldas C, Hahn SA, da Costa LT, Redston MS, Schutte M, Seymour AB, Weinstein CL, Hruban RH, Yeo CJ, Kern SE: Frequent somatic mutations and homozygous deletions of the p16 (MTS1) gene in pancreatic adenocarcinoma. Nat Genet 1994;8:27-32.

8 Rozenblum E, Schutte M, Goggins M, Hahn SA, Panzer S, Zahurak M, Goodman SN, Sohn TA, Hruban RH, Yeo CJ, Kern SE: Tumorsuppressive pathways in pancreatic carcinoma. Cancer Res 1997;57:1731-1734.

9 Wilentz RE, Geradts J, Maynard R, Offerhaus GJ, Kang M, Goggins M, Yeo CJ, Kern SE, Hruban RH: Inactivation of the p16 (INK4A) tumor-suppressor gene in pancreatic duct lesions: Loss of intranuclear expression. Cancer Res 1998;58:4740-4744.

10 Boschman CR, Stryker S, Reddy JK, Rao MS: Expression of $\mathrm{p} 53$ protein in precursor lesions and adenocarcinoma of human pancreas. Am J Pathol 1994;145:1291-1295.
11 Apple SK, Hecht JR, Lewin DN, Jahromi SA, Grody WW, Nieberg RK: Immunohistochemical evaluation of K-ras, p53, and HER-2/neu expression in hyperplastic, dysplastic, and carcinomatous lesions of the pancreas: Evidence for multistep carcinogenesis. Hum Pathol 1999;30:123-129.

12 Löhr M, Müller P, Mora J, Brinkmann B, Ostwald C, Farre A, Lluis F, Adam U, J. Stubbe J, Plath F, Nizze H, Hopt UT, Barten M, Capella G, Liebe S: p53 and K-ras mutations in pancreatic juice samples from patients with chronic pancreatitis. Gastrointest Endosc 2001;53:734-743.

13 Wilentz RE, Iacobuzio-Donahue CA, Argani P, McCarthy DM, Parsons JL, Yeo CJ, Kern SE, Hruban RH: Loss of expression of Dpc4 in pancreatic intraepithelial neoplasia: Evidence that DPC4 inactivation occurs late in neoplastic progression. Cancer Res 2000;60:20022006.

14 Liang P, Pardee AB: Differential display. A general protocol. Mol Biotechnol 1998;10:261267.

15 Hubank M, Schatz DG: Identifying differences in mRNA expression by representational difference analysis of cDNA. Nucleic Acids Res 1994;22:5640-5648

16 Backhaus C, Schneuer S, Jesnowski R, Liebe S, Löhr M: Differentially expressed genes in normal and tumor pancreatic tissue. Ann NY Acad Sci 1999;880:166-170.

17 Gress TM, Wallrapp C, Frohme M, Müller-Pillasch F, Lacher U, Friess H, Büchler M, Adler $\mathrm{G}$, Hoheisel JD: Identification of genes with specific expression in pancreatic cancer by cDNA representational difference analysis. Genes Chromosomes Cancer 1997;19:97-103.

18 Grützmann R, Pilarsky C, Staub E, Schmitt AO, Foerder M, Specht T, Hinzmann B, Dahl E, Alldinger I, Rosenthal A, Ockert D, Saeger HD: Systematic isolation of genes differentially expressed in normal and cancerous tissue of the pancreas. Pancreatology 2003;3:169-178.

19 Gillespie D, Spiegelman S: A quantitative assay for DNA-RNA hybrids with DNA immobilized on a membrane. J Mol Biol 1965;12: 829-842.

20 Southern EM: Detection of specific sequences among DNA fragments separated by gel electrophoresis. J Mol Biol 1975;98:503-517.
21 Poustka A, Pohl T, Barlow DP, Zehetner G, Craig A, Michiels F, Ehrich E, Frischauf AM, Lehrach H: Molecular approaches to mammalian genetics. Cold Spring Harb Symp Quant Biol 1986;51:131-139.

22 Gress TM, Hoheisel JD, Lennon GG, Zehetner $\mathrm{G}$, Lehrach $\mathrm{H}$ : Hybridization fingerprinting of high-density cDNA-library arrays with cDNA pools derived from whole tissues. Mamm Genome 1992;3:609-619.

23 Maskos U, Southern EM: Oligonucleotide hybridizations on glass supports: A novel linker for oligonucleotide synthesis and hybridization properties of oligonucleotides synthesised in situ. Nucleic Acids Res 1992;20:1679-1684.

24 Fodor SP, Read JL, Pirrung MC, Stryer L, Lu AT, Solas D: Light-directed, spatially addressable parallel chemical synthesis. Science 1991; 251:767-773.

25 Schena M, Shalon D, Davis RW, Brown PO: Quantitative monitoring of gene expression patterns with a complementary DNA microarray. Science 1995;270:467-470.

26 Cheung VG, Morley M, Aguilar F, Massimi A, Kucherlapati R, Childs G: Making and reading microarrays. Nat Genet 1999;21(suppl):1519.

27 Buchholz M, Boeck W, Fensterer H, Muller F, Wenger C, Michl P, Adler G, Gress TM: Use of DNA arrays/microarrays in pancreatic research. Pancreatology 2001;1:581-586.

28 Duggan DJ, Bittner M, Chen Y, Meltzer P, Trent JM: Expression profiling using cDNA microarrays. Nat Genet 1999;21(suppl):10 14.

29 Holloway AJ, van Laar RK, Tothill RW, Bowtell DD: Options available - from start to finish - for obtaining data from DNA microarrays II. Nat Genet 2002;32(suppl):481-489.

30 Lipshutz RJ, Fodor SP, Gingeras TR, Lockhart DJ: High density synthetic oligonucleotide arrays. Nat Genet 1999;21(suppl):20-24. 
31 Baum M, Bielau S, Rittner N, Schmid K, Eggelbusch K, Dahms M, Schlauersbach A, Tahedl H, Beier M, Guimil R, Scheffler M, Hermann C, Funk JM, Wixmerten A, Rebscher A, Honig M, Andreae C, Buchner D, Moschel E, Glathe A, Jager E, Thom M, Greil A, Bestvater F, Obermeier F, Burgmaier J, Thome K, Weichert S, Hein S, Binnewies T, Foitzik V, Muller M, Stahler CF, Stahler PF: Validation of a novel, fully integrated and flexible microarray benchtop facility for gene expression profiling. $\mathrm{Nu}$ cleic Acids Res 2003;31:e151.

32 Chakravarti A: Population genetics - Making sense out of sequence. Nat Genet 1999; 21(suppl):56-60.

33 Schwaenen C, Nessling M, Wessendorf S, Salvi T, Wrobel G, Radlwimmer B, Kestler HA, Haslinger C, Stilgenbauer S, Dohner H, Bentz M, Lichter P: Automated array-based genomic profiling in chronic lymphocytic leukemia: Development of a clinical tool and discovery of recurrent genomic alterations. Proc Natl Acad Sci USA 2004;101:1039-1044.

34 Lofton-Day C, Lesche R: DNA methylation markers in patients with gastrointestinal cancers. Current understanding, potential applications for disease management and development of diagnostic tools. Dig Dis 2003;21:299308.

35 van't Veer LJ, Dai H, van de Vijver MJ, He JD, Hart AA, Mao M, Peterse HL, van der Kooy K, Marton MJ, Witteveen AT, Schreiber GJ Kerkhoven RM, Roberts C, Linsley PS, Bernards R, Friend SH: Gene expression profiling predicts clinical outcome of breast cancer. $\mathrm{Na}$ ture 2002;415:530-536.

36 Notterman DA, Alon U, Sierk AJ, Levine AJ: Transcriptional gene expression profiles of colorectal adenoma, adenocarcinoma, and normal tissue examined by oligonucleotide arrays. Cancer Res 2001;61:3124-3130.

37 Alon U, Barkai N, Notterman DA, Gish K, Ybarra S, Mack D, Levine AJ: Broad patterns of gene expression revealed by clustering analysis of tumor and normal colon tissues probed by oligonucleotide arrays. Proc Natl Acad Sci USA 1999;96:6745-6750.

38 Yanagawa R, Furukawa Y, Tsunoda T, Kitahara $\mathrm{O}$, Kameyama $\mathrm{M}$, Murata $\mathrm{K}$, Ishikawa $\mathrm{O}$, Nakamura Y: Genome-wide screening of genes showing altered expression in liver metastases of human colorectal cancers by cDNA microarray. Neoplasia 2001;3:395-401.

39 Luo J, Duggan DJ, Chen Y, Sauvageot J, Ewing CM, Bittner ML, Trent JM, Isaacs WB: Human prostate cancer and benign prostatic hyperplasia: Molecular dissection by gene expression profiling. Cancer Res 2001;61:46834688.

40 Selaru FM, Zou T, Xu Y, Shustova V, Yin J, Mori Y, Sato F, Wang S, Olaru A, Shibata D, Greenwald BD, Krasna MJ, Abraham JM, Meltzer SJ: Global gene expression profiling in Barrett's esophagus and esophageal cancer: A comparative analysis using cDNA microarrays. Oncogene 2002;21:475-478.
41 Hippo Y, Taniguchi H, Tsutsumi S, Machida N, Chong JM, Fukayama M, Kodama T, Aburatani $\mathrm{H}$ : Global gene expression analysis of gastric cancer by oligonucleotide microarrays. Cancer Res 2002;62:233-240.

42 Argani P, Rosty C, Reiter RE, Wilentz RE, Murugesan SR, Leach SD, Ryu B, Skinner HG, Goggins M, Jaffee EM, Yeo CJ, Cameron JL, Kern SE, Hruban RH: Discovery of new markers of cancer through serial analysis of gene expression: Prostate stem cell antigen is overexpressed in pancreatic adenocarcinoma. Cancer Res 2001;61:4320-4324.

43 Ryu B, Jones J, Blades NJ, Parmigiani G, Hollingsworth MA, Hruban RH, Kern SE: Relationships and differentially expressed genes among pancreatic cancers examined by largescale serial analysis of gene expression. Cancer Res 2002;62:819-826.

44 Friess H, Ding J, Kleeff J, Liao Q, Berberat PO, Hammer J, Büchler MW: Identification of disease-specific genes in chronic pancreatitis using DNA array technology. Ann Surg 2001;234: 769-779.

45 Crnogorac-Jurcevic T, Efthimiou E, Nielsen T, Loader J, Terris B, Stamp G, Baron A, Scarpa A, Lemoine NR: Expression profiling of microdissected pancreatic adenocarcinomas. Oncogene 2002;21:4587-4594.

46 Han H, Bearss DJ, Browne LW, Calaluce R, Nagle RB, Von Hoff DD: Identification of differentially expressed genes in pancreatic cancer cells using cDNA microarray. Cancer Res 2002;62:2890-2896.

47 Iacobuzio-Donahue CA, Maitra A, Shen-Ong GL, van Heek T, Ashfaq R, Meyer R, Walter K, Berg K, Hollingsworth MA, Cameron JL, Yeo CJ, Kern SE, Goggins M, Hruban RH: Discovery of novel tumor markers of pancreatic cancer using global gene expression technology. Am J Pathol 2002;160:1239-1249.

48 Tan ZJ, Hu XG, Cao GS, Tang Y: Analysis of gene expression profile of pancreatic carcinoma using cDNA microarray. World J Gastroenterol 2003;9:818-823.

49 Iacobuzio-Donahue CA, Maitra A, Olsen M, Lowe AW, van Heek NT, Rosty C, Walter K, Sato N, Parker A, Ashfaq R, Jaffee E, Ryu B, Jones J, Eshleman JR, Yeo CJ, Cameron JL, Kern SE, Hruban RH, Brown PO, Goggins M: Exploration of global gene expression patterns in pancreatic adenocarcinoma using cDNA microarrays. Am J Pathol 2003;162:1151-1162.

50 Logsdon CD, Simeone DM, Binkley C, Arumugam T, Greenson JK, Giordano TJ, Misek DE, Kuick R, Hanash S: Molecular profiling of pancreatic adenocarcinoma and chronic pancreatitis identifies multiple genes differentially regulated in pancreatic cancer. Cancer Res 2003; 63:2649-2657.

51 Grützmann R, Foerder M, Alldinger I, Staub E, Brummendorf T, Ropcke S, Li X, Kristiansen G, Jesnowski R, Sipos B, Löhr M, Lüttges J, Ockert D, Klöppel G, Saeger HD, Pilarsky C: Gene expression profiles of microdissected pancreatic ductal adenocarcinoma. Virchows Arch 2003;443:508-517.
52 Crnogorac-Jurcevic T, Missiaglia E, Blaveri E, Gangeswaran R, Jones M, Terris B, Costello E, Neoptolemos JP, Lemoine NR: Molecular alterations in pancreatic carcinoma: expression profiling shows that dysregulated expression of S100 genes is highly prevalent. J Pathol 2003; 201:63-74.

53 Friess H, Ding J, Kleeff J, Fenkell L, Rosinski JA, Guweidhi A, Reidhaar-Olson JF, Korc M, Hammer J, Büchler MW: Microarray-based identification of differentially expressed growth- and metastasis-associated genes in pancreatic cancer. Cell Mol Life Sci 2003;60: 1180-1199.

54 Iacobuzio-Donahue CA, Ashfaq R, Maitra A, Adsay NV, Shen-Ong GL, Berg K, Hollingsworth MA, Cameron JL, Yeo CJ, Kern SE, Goggins M, Hruban RH: Highly expressed genes in pancreatic ductal adenocarcinomas: A comprehensive characterization and comparison of the transcription profiles obtained from three major technologies. Cancer Res 2003;63: 8614-8622.

55 Terris B, Blaveri E, Crnogorac-Jurcevic T Jones M, Missiaglia E, Ruszniewski P, Sauvanet A, Lemoine NR: Characterization of gene expression profiles in intraductal papillary-mucinous tumors of the pancreas. Am J Pathol 2002; 160:1745-1754.

56 Sager R: Expression genetics in cancer: Shifting the focus from DNA to RNA. Proc Natl Acad Sci USA 1997;94:952-955.

57 M. Löhr and H. Friess: The risk of pancreatic surgery (in German). Z Gastroenterol 2003;41: 475-477.

58 Bilban M, Buehler LK, Head S, Desoye G, Quaranta V: Normalizing DNA microarray data. Curr Issues Mol Biol 2002;4:57-64.

59 Hoffmann R, Seidl T, Dugas M: Profound effect of normalization on detection of differentially expressed genes in oligonucleotide microarray data analysis. Genome Biol 2002;3: RESEARCH0033.

60 van de Peppel J, Kemmeren P, van Bakel H, Radonjic M, van Leenen D, Holstege FC: Monitoring global messenger RNA changes in externally controlled microarray experiments. EMBO Rep 2003;4:387-393.

61 Tusher VG, Tibshirani R, Chu G: Significance analysis of microarrays applied to the ionizing radiation response. Proc Natl Acad Sci USA 2001;98:5116-5121.

62 Brazma A, Hingamp P, Quackenbush J, Sherlock G, Spellman P, Stoeckert C, Aach J, Ansorge W, Ball CA, Causton HC, Gaasterland T, Glenisson P, Holstege FC, Kim IF, Markowitz V, Matese JC, Parkinson H, Robinson A, Sarkans U, Schulze-Kremer S, Stewart K, Taylor $\mathrm{R}$, Vilo J, Vingron M: Minimum information about a microarray experiment (MIAME)-toward standards for microarray data. Nat Genet 2001;29:365-371.

63 Rhodes DR, Barrette TR, Rubin MA, Ghosh D, Chinnaiyan AM: Meta-analysis of microarrays: Interstudy validation of gene expression profiles reveals pathway dysregulation in prostate cancer. Cancer Res 2002;62:4427-4433. 
64 Fink L, Seeger W, Ermert L, Hanze J, Stahl U, Grimminger F, Kummer W, Bohle RM: Realtime quantitative RT-PCR after laser-assisted cell picking. Nat Med 1998;4:1329-1333.

65 Kuo WP, Jenssen TK, Butte AJ, Ohno-Machado L, Kohane IS: Analysis of matched mRNA measurements from two different microarray technologies. Bioinformatics 2002;18: 405-412.

66 Grützmann R, Lüttges J, Sipos B, Ammerpohl O, Dobrowolski F, Alldinger I, Kersting S, Ockert D, Koch R, Kalthoff H, Schackert HK, Saeger H-D, Kloeppel G, Pilarsky C: ADAM9 overexpression in pancreatic ductual adenocarcinoma is associated with tumor type and prognosis. Br J Cancer 2004; 90:1053-1058.

67 Moll R: Cytokeratins in the histological diagnosis of malignant tumors. Int $\mathbf{J}$ Biol Markers 1994;9:63-69.
68 Sinha P, Hutter G, Kottgen E, Dietel M, Schadendorf $\mathrm{D}$, Lage $\mathrm{H}$ : Increased expression of epidermal fatty acid binding protein, cofilin, and 14-3-3-sigma (stratifin) detected by twodimensional gel electrophoresis, mass spectrometry and microsequencing of drug-resistant human adenocarcinoma of the pancreas. Electrophoresis 1999;20:2952-2960.

69 Juhl H, Helmig F, Baltzer K, Kalthoff H, Henne-Bruns D, Kremer B: Frequent expression of complement resistance factors CD46, CD55, and CD59 on gastrointestinal cancer cells limits the therapeutic potential of monoclonal antibody 17-1A. J Surg Oncol 1997;64: 222-230.

70 Touab M, Villena J, Barranco C, Arumi-Uria M, Bassols A: Versican is differentially expressed in human melanoma and may play a role in tumor development. Am J Pathol 2002; 160:549-557.

71 Chang YS, Kong G, Sun S, Liu D, El-Naggar AK, Khuri FR, Hong WK, Lee HY, Gong K: Clinical significance of insulin-like growth factor-binding protein-3 expression in stage I nonsmall cell lung cancer. Clin Cancer Res 2002;8: 3796-3802.
72 Schmid MC, Bisoffi M, Wetterwald A, Gautschi E, Thalmann GN, Mitola S, Bussolino F, Cecchini MG: Insulin-like growth factor binding protein-3 is overexpressed in endothelial cells of mouse breast tumor vessels. Int J Cancer 2003; 103:577-586.

73 Ilantzis C, DeMarte L, Screaton RA, Stanners CP: Deregulated expression of the human tumor marker CEA and CEA family member CEACAM6 disrupts tissue architecture and blocks colonocyte differentiation. Neoplasia 2002;4:151-163.

74 Kristiansen G, Schluns K, Yongwei Y, Denkert C, Dietel M, Petersen I: CD24 is an independent prognostic marker of survival in nonsmall cell lung cancer patients. Br J Cancer 2003;88: 231-236.

75 Esposito I, Bauer A, Hoheisel JD, Kleeff J, Friess H, Bergmann F, Rieker RJ, Otto HF, Kloppel G, Penzel R: Microcystic tubulopapillary carcinoma of the pancreas: A new tumor entity? Virchows Arch 2004;444:447-453. 